\title{
В.Н. Фатеенков
}

\section{Федеральное государственное бюджетное учреждение} "27 Научный чентр» Министерства обороны Российской Федерации, 105005, Российская Федерация, г. Москва, Бригадирский переулок, д. 13

Поступила 19.05.2020 г. Принята к публикации 31.05.2020 г.

Конвенция о запрещении разработки, производства, накопления и применения химического оружия и о его уничтожении (КЗХО) была принята Генеральной Ассамблеей ООН 30 ноября 1992 г. Вступила в силу 29 апреля 1997 г. Цель работь - рассмотреть историю подписания и основные положения КЗХО. Попытки разработать международное соглашение, ограничивающее применение ядов и различных токсических веществ в боевых действиях, предпринимались еще в XVII в., когда в 1675 г. в Страсбурге между Францией и Германией (Священной Римской империей) было заключено соглашение о неприменении отравленных пуль. В ходе Первой и Второй мирных конференций в Гааге (1899 г. и 1907 г.) ее участники обязались не употреблять в ходе военных действий яд или отравленное оружие, а также оружие, снаряды и вещества, способные причинять излишние страдания. Первая Мировая война показала, что этот запрет оказался не действенным, так что химическое оружие появилось на поле боя. После войны был разработан Протокол «О запрещении применения на войне удушающих, ядовитых и других подобных газов, и бактериологических средств», известный как Женевский протокол 1925 г. Он не запрещал присоединившимся к нему государствам разрабатывать и производить химическое оружие. Они брали на себя обязательство его не применять в отношении государств, присоединившихся к Протоколу, а также сохраняли за собой право на ответное применение химического оружия, этим «правом» гарантировалось соблюдение Протокола. Однако, как показала ирано-иракская война (1980-1988 гг.), в отношении государства, не обладающего химическим оружием, такая гарантия могла не сработать. Широкое применение Ираком химического оружия против иранских войск ускорило процесс разработки международно-правового документа - КЗХО, первого в мире многостороннего соглашения по разоружению, предусматривающего в течение установленного срока ликвидацию целого класса оружия массового поражения - химического. К настоящему времени к ней присоединились 192 государства. Российская Федерация полностью выполнила взятые на себя в рамках КЗХО обязательства - в сентябре 2017 г. был уничтожен последний российский химический боеприпас.

Ключевые слова: Женевский протокол 1925 г.; Конвенияя о запрещзении химического оружия (КЗХО); Конвенция о запрещении биологического и токсинного оружия (КБТО); Организация Объединенных Наций (ООН); Организация по запрещению химического оружия (ОЗХО); отравляющие вещества; токсичные химикаты; уничтожение; химическое оружие.

Библиографическое описание: Фатеенков В.Н. Конвенияя о запрещении разработки, производства, накопления и применения химического оружия и о его уничтожении: история подписания, основные положения // Вестник войск РХБ защиты. 2020. Т. 4. № 2. С. 104-115. https://doi.org/10.35825/2587-5728-2020-4-2-104-115 
Конвенция о запрещении разработки, производства, накопления и применения химического оружия и о его уничтожении (далее - КЗХО, Конвенция) - первое в мире многостороннее соглашение по разоружению, предусматривающее в течение установленного срока ликвидацию целого класса оружия массового поражения. Цель работь - рассмотреть историю подписания и основные положения K3XO.

История Конвенции о запрещении разработки, производства, накопления и применения химического оружия и о его уничтожении. Применение токсичных химикатов в качестве оружия известно с древнейших времен. Еще в каменном веке люди применяли едкий дым костра, выкуривая животных из их логова. Затем, познакомившись с растительными и животными ядами, люди начали использовать их не только на охоте, но и на войне. В китайской рукописи, датированной IV в. до н.э., упоминается об использовании ядовитых газов для борьбы с подкопами врага под стены крепостей. Использовали отравляющие вещества в своих войнах, например, древние греки: так, в ходе Пелопоннесской войны (431-404 гг. до н.э.) спартанцы подкладывали под стены осаждаемых городов горящие бревна, начиненные смолой и серой [1]. Однако применение токсичных химикатов всегда осуждалось человеческим сообществом, поскольку ассоциировалось с неоправданной жестокостью, выходящей за рамки «цивилизованной» войны.

Первое международное соглашение, ограничивающее применение химического оружия, было заключено еще в 1675 г. в Страсбурге между Францией и Германией (Священной Римской империей), которые договорились запретить применение отравленных пуль [2]. Почти через двести лет, в 1874 г., было принято второе подобное соглашение. Это была Брюссельская декларация о законах и обычаях войны. Она запрещала применять яды и ядовитое оружие, а также оружие, снаряды и вещества, причиняющие неоправданные страдания людям. Правда, это соглашение так и не вступило в силу [3].

Затем, в ходе Первой мирной конференции в Гааге в 1899 г., созванной по инициативе Российского императора Николая II, ее участники приняли, в частности, конвенцию «О законах и обычаях сухопутной войны», а также декларацию «О неупотреблении снарядов, имеющих единственным назначением распространять удушающие или вредоносные газы», где обязались «воздерживаться от применения снарядов, исключительной целью которых является распыление удушающих или вредных газов» (рисунок 1). В ходе Второй мирной конференции в

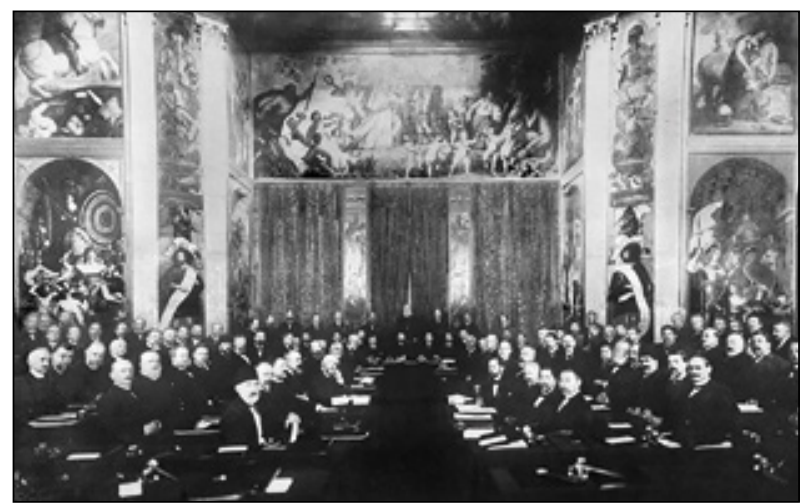

Рисунок 1 - Первая межкународная мирная конференция в Гааге, июнь 18992. (фотография из архива автора)

Гааге (1907 г.) были подтверждены предыдущие запреты на применение отравляющих или отравленных вооружений [2].

Несмотря на эти меры, во время Первой Мировой войны токсичные химикаты стали использоваться в беспрецедентных масштабах для достижения военных целей. Первое масштабное боевое применение химического оружия произошло на Восточном фронте во время германского наступления 31 января 1915 г. восточнее польского города Болимов. По русским позициям было выпущено 18 тыс. 15-см снарядов, доставивших 72 т смеси бромистого ксилила и бромистого ксилилена. Однако летучесть этих ОВ оказалась в условиях холодной зимы недостаточной для создания концентраций их паров, при которых возможно достижение боевого эффекта. Следующее применение германской армией химического оружия, имевшее место 22 апреля 1915 г. на Западном фронте, оказалось более смертоносным для противника. На фронте атаки в 6 км было установлено 6 тыс. баллонов с хлором, собранных в газовые батареи по 20 баллонов в каждой. Газопуск проведен 22 апреля в 17 ч. Выпущено 180 т хлора. Для французских частей газопуск обернулся катастрофой. Фронт перестал существовать в полосе 8 км, глубина прорыва германских частей достигла 5 км. У союзников хлором было отравлено не менее 15 тыс. человек, из них умерли около 5 тыс. Так химическое оружие пришло на поле боя [4].

Всего воюющими сторонами за годы войны произведено 180 тыс. т различных ОВ, в ходе боевых действий было применено 125 тыс. т ОВ. Проверку в боевых условиях прошли не менее 45 различных токсических веществ, среди них 4 кожно-нарывного действия, 14 удушающих и, по крайней мере, 27 инкапаситирующих [5]. Общие потери от химического оружия оценить трудно, в разных источниках приводятся разные цифры, от сотен тысяч до полутора миллионов 


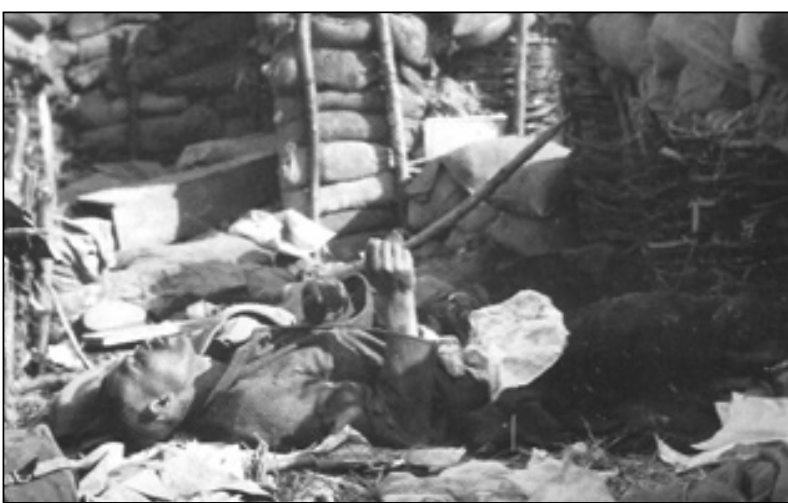

Рисунок 2 - Одна из первых жертв химической войны - французский солдат, погибший во время газобаллонного нападения немцев 22.04.1915 2. под Ипром.

Фотография из работы J. Simon, R. Hook [7]

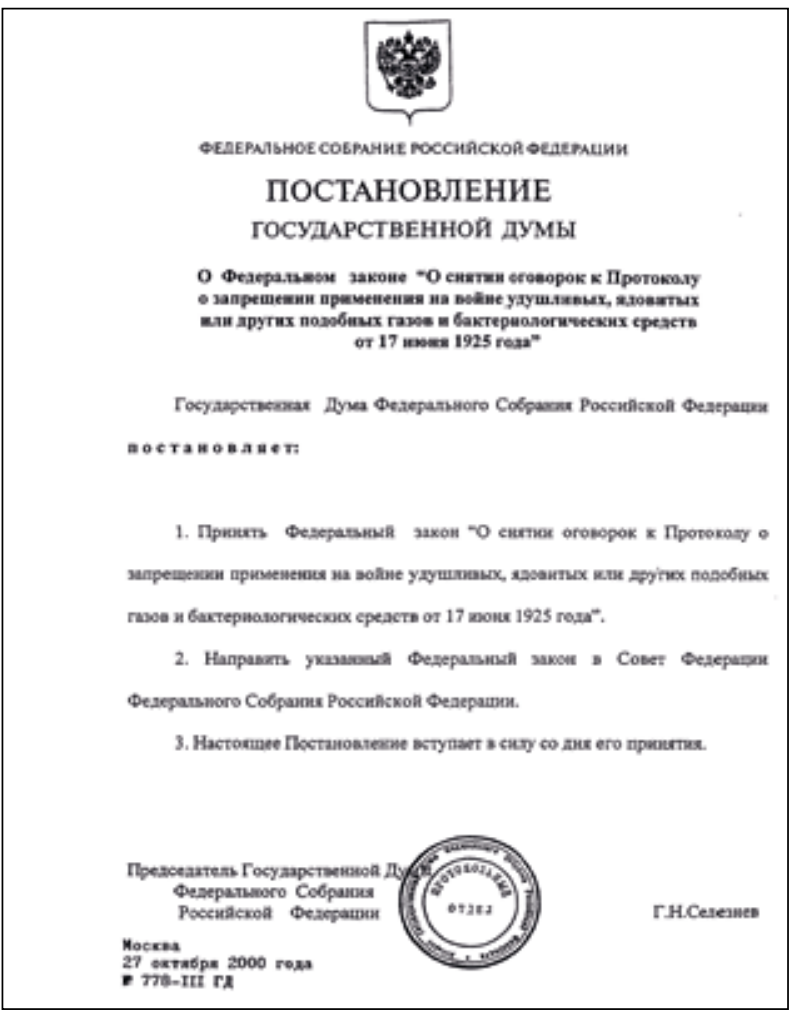

Рисунок 3 - Постановление Государственной Думы Федерального Собрания Российской Федерации "О Федеральном Законе "О снятии оговорок к Протоколу о запрещении применения на войне удушающих, ядовитых и других подобных газов, и бактериологических средств om 17 июня 1925 года» (URL: https://duma. consultant.ru/documents/667631; дата обращения: 14.03.2020)

человек. Более точна статистика по погибшим. По данным историка Б.Ц. Урланиса [6], от ОВ на поле боя и этапах медицинской эвакуации погибло не менее 39 тыс. человек (рисунок 2) ${ }^{1}$.

Возмущение общественности в связи с ужасами применения химического оружия в ходе военных действий привело к тому, что после Первой Мировой войны стали проводиться переговоры по заключению новых правовых документов, направленных на недопущение такого применения впредь. Самым известным из них стал Протокол 1925 г. «О запрещении применения на войне удушающих, ядовитых и других подобных газов, и бактериологических средств», широко известный как Женевский протокол 1925 г. Однако по Женевскому протоколу не запрещалась разработка, производство химического оружия и обладание им. Он запрещал лишь применение химического и бактериологического (биологического) оружия в ходе войны [9]. Кроме того, многие страны присоединились к данному протоколу с оговорками, которые позволяли им применять химическое оружие против стран, не подписавших этот протокол, а также реагировать аналогичным образом на нападения с применением химического оружия против них (рисунок 3).

Озабоченность по поводу ядерного оружия, существовавшая в течение почти всего периода после Второй Мировой войны, отодвинула тему химического оружия на второй план, пока о ней не вспомнили со всей серьезностью в 1968 г., когда на Конференции по разоружению в Женеве началось обсуждение биологического и химического оружия.

Эти дискуссии, хотя и разными путями, привели к заключению соответствующих договоров. «Конвенция о запрещении разработки, производства и накопления запасов бактериологического (биологического) и токсинного оружия и об их уничтожении» (далее - КБТО) была заключена достаточно быстро. Она была открыта для подписания 10 апреля 1972 г. и вступила в силу 26 марта 1975 г. В статью IX этой конвенции было включено обязательство «продолжать переговоры для достижения в ближайшем будущем соглашения об эффективных мерах по запрещению его разработки, производства и накопления запасов и его уничтожению и о соответствующих мерах в отношении оборудования и средств доставки, специально предназначенных для производства либо использования химических агентов в качестве оружия» [10].

Переговоры по КЗХО длились намного дольше, проходили с большими дискуссиями, а прорывы были связаны с изменениями в политической и других областях. В 1980 г., на 
Конференции по разоружению, была создана специальная рабочая группа по химическому оружию, впоследствии эта рабочая группа обновлялась каждый год вплоть до принятия Конвенции. В 1984 г. Конференция по разоружению перешла к разработке непосредственно текста будущей конвенции о запрещении химического оружия [11].

В том же году (и за год до возобновления двусторонних переговоров между США и СССР) Соединенные Штаты представили свой проект КЗХО, многие положения которого были включены в так называемый текущий текст договора, основная структура его была определена тогда же. Тем не менее, фактически для США эти переговоры были скорее ширмой для развертывания новой программы производства бинарного химического оружия, запущенной в 1987 г. В американский проект КЗХО были включены положения об инспекции по запросу с коротким периодом уведомления, в любое время, в любом месте и без права отказа. Такой механизм проверки был неприемлем для Советского Союза и переговоры были заблокированы [11].

В 1982-1988 гг. Генеральная Ассамблея постоянно выражала свое сожаление и озабоченность в связи с тем, что разработка конвенции не была завершена, и настоятельно призывала Конференцию по разоружению активизировать переговоры. Однако применение Ираком химического оружия в ходе ираноиракской войны 1980-1988 гг., а также угроза расползания по разным странам химического оружия, которое потенциально может быть произведено даже на сравнительно низком технологическом уровне, все же активизировали переговорный процесс [11]. Изменилась и политическая ситуация: в 1987 г., на волне перестройки, Советский Союз согласился на установление режима инспекций с коротким сроком уведомления и без права на отказ для проверки выполнения будущей КЗХО $[11,12]$. Однако подобный интрузивный механизм в отношении КЗХО оказался неприемлем для самих США. И в июле 1991 г. США, Великобритания, Япония и Австралия выступили с предложением внести в текст конвенции положение о менее интрузивных инспекциях, нежели те, которые ранее поддержал Советский Союз [13].

Несмотря на все трудности, переговоры по химическому разоружению продолжались в различных форматах, как на многостороннем, так и на двустороннем уровне. На Сорок третьей сессии Генеральной Ассамблеи в 1988 г. Соединенные Штаты предложили созвать конференцию для рассмотрения мер для поддержки авторитета и для «обращения вспять серьезной эрозии» Женевского протокола 1925 г. $^{2}$ Франция предложила себя в качестве принимающей стороны конференции, которая позднее прошла в Париже с 7 по 11 января 1989 г. В Заключительной декларации Конференции государств-участников Женевского протокола 1925 г. (Парижская конференция) признавались значение и непреходящая действенность Женевского протокола 1925 г., а также содержался призыв к Конференции по разоружению удвоить свои усилия по заключению КЗХО弓

23 сентября 1989 г. СССР и США подписали Меморандум о понимании относительно двустороннего эксперимента по контролю и обмену данными в связи с запрещением химического оружия (Вайомингский меморандум $)^{4}$, предусматривавший обмен информацией по запасам химического оружия и объектам по его производству, а также проведение взаимных посещений соответствующих объектов. 1 июня 1990 г. было подписано Соглашение между СССР и США об уничтожении и непроизводстве химического оружия и о мерах по содействию многосторонней конвенции о запрещении химического оружия, которое, правда, так и не вступило в силу в связи с завершением согласования многосторонней конвенции. По этому Соглашению у каждой из сторон должно было остаться не более 5 тыс. т отравляющих веществ после 2002 г. В 1991-1992 гг. многие другие страны также заключили многосторонние и двусторонние соглашения, содержащие обязательства об отказе от обладания, разработки, производства и приобретения химического оружия: Аргентина, Бразилия и Чили - 5 сентября 1991 г., страны Андской группы - 4 декабря 1991 г., Индия и Пакистан - 19 августа

Provisional verbatim record of the 4th meeting, held at Headquarters, New York, on Monday, 26 September 1988: General Assembly, 43rd session. P.33. URL: http://dag.un.org/bitstream/handle/11176/162715/A_43_PV.4-EN. pdf?sequence=1\&isAllowed=y (дата обращения: 14.03.2020).

3 Заключительная декларация Конференции государств-участников Женевского протокола 1925 года и других заинтересованных государств. Письмо постоянного представителя Франции при ООН от 19.01.1989 на имя Генерального Секретаря. С. 2. URL: http://dag.un.org/bitstream/handle/11176/144777/A_44_88-RU. pdf?sequence=5\&isAllowed=y (дата обращения: 14.03.2020).

4 Joint statement on chemical weapons. Letter dated 89/09/25 from the Minister for Foreign Affairs of the Union of Soviet Socialist Republics and the Secretary of State of the United States of America addressed to the SecretaryGeneral. URL: http://dag.un.org/bitstream/handle/11176/143980/A_C.1_44_2- EN.pdf?sequence=1\&isAllowed=y (дата обращения: 14.03.2020). 
1992 г. После распада Советского Союза, 15 мая 1992 г., в Ташкенте Азербайджан, Армения, Казахстан, Кыргызстан, Молдова, Российская Федерация, Таджикистан, Туркменистан и Узбекистан подписали соглашение в отношении химического оружия. По этому соглашению стороны, отмечая, что все объекты по хранению и производству химического оружия размещены на территории Российской Федерации, подтвердили обязательства бывшего СССР по Женевскому протоколу 1925 г. [11].

В ноябре 1991 г. СБ ООН была принята резолюция № $678^{5}$, в соответствии с которой был впервые санкционирован международный режим инспекций, имеющий цель уничтожение ОМП Ирака, и создана специальная комиссия $\mathrm{OOH}$, которая должна была заниматься поиском и уничтожением такого оружия (ЮНСКОМ) непосредственно на территории Ирака. Действия ЮНСКОМ, правовой режим, предоставленный ей СБ OOH, стали отработкой основных положений КЗХО по контролю над химическим оружием [14].

В 1992 г. было устранено еще одно важное противоречие, когда США отказались от требования сохранить в тексте КЗХО возможность ответного удара тем же оружием, и, соответственно, сняли условие о сохранении запасов безопасности ${ }^{6}$.

Конференция по разоружению 3 сентября 1992 г. утвердила доклад, содержащий текст проекта КЗХО, и решила путем консенсуса препроводить проект конвенции Генеральной Ассамблее. По рекомендации Первого комитета Генеральная Ассамблея в своей резолюции 47/39 от 30 ноября 1992 г. дала высокую оценку Конвенции. Она далее просила Генерального секретаря открыть ее для подписания в Париже 13 января 1993 г. [15].

По просьбе Генеральной Ассамблеи ООН, Генеральный Секретарь $\mathrm{OOH}$, как депозитарий данной Конвенции, открыл ее для подписания 13 января 1993 г. в Париже. На конференции в Париже, организованной для подписания КЗХО и длившейся в течение трех дней, 130 стран подписали данную Конвенцию7.
Государства-участники КЗХО признали, что до ее вступления в силу необходимо провести серьезную подготовительную работу и урегулировать ряд нерешенных вопросов. Поэтому во время церемонии подписания в Париже одновременно была принята специальная резолюция (так называемая Парижская резолюция), учредившая Подготовительную комиссию для будущей Организации по запрещению химического оружия (далее - O3XO). Комиссия была призвана создать условия, обеспечивающие функционирование ОЗХО сразу после вступления в силу Конвенции, в том числе проведение первой конференции государств-участников. В соответствии с резолюцией комиссия в качестве самостоятельной международной организации наделялась «такой правосубъектностью, которая необходима для осуществления ее функций и достижения ее целей» ${ }^{8}$. В сферу деятельности Подготовительной комиссии входили административно-финансовые и правовые вопросы, а также вопросы осуществления отдельных элементов режима КЗХО, детализация или решение которых в тексте конвенции были отнесены к ведению ОЗХО. Инаугурационная сессия Подготовительной комиссии прошла в феврале 1993 г. в Гааге, где в будущем заработала ОЗХО. Всего состоялось 16 пленарных сессий комиссии, последнее из них - незадолго до вступления Конвенции в силу, 9-15 апреля 1997 г. [11].

Подготовительная комиссия в рамках своего мандата успешно решила ряд задач, что было отражено в заключительном докладе. В число ее основных достижений вошли решение вопросов, связанных с принципами формирования и состава списков химикатов, подлежащих контролю, с механизмом проверки исполнения КЗХO, с определением ключевых терминов, относящихся к химическому оружию, создание лаборатории O3XO, разработка общей схемы подготовки инспекторов, урегулирование вопросов, касающихся нового здания штаб-квартиры $\mathrm{O} \mathrm{XO}^{9}$, а также разработка проектов соглашений, необходимых для

\footnotetext{
Резолюция Совета Безопасности ООН № 687 (1991) от 3 апреля 1991 г. «Ситуация в отношениях между Ираком и Кувейтом». URL: https:/online.zakon.kz/Document/?doc_id=35634502\#pos=4;-109 (дата обращения: 14.03.2020).

6 Genesis and Historical Development. Organisation for the Prohibition of Chemical Weapons. URL: https://www. opcw.org/chemical-weapons-convention/genesis-and-historical-development/ (дата обращения: 14.03.2020).

United Nations Treaty Collection. Convention on the Prohibition of the Development, Production, Stockpiling and Use of Chemical Weapons and on their Destruction. URL: https://reaties.un.org/Pages/ViewDetails. aspx?src=TREATY\&mtdsg_no=XXVI3\&chapter=26\&lang=en (дата обращения: 14.03.2020).

8 Resolution Establishing the Preparatory Commission for the Organisation for the Prohibition of Chemical Weapons URL: https://www.opcw.org/fileadmin/OPCW/CWC/disarm_negotiat_history/Paris_resolution.pdf (дата обращения: 14.03.2020).

9 Опыт решения таких задач ранее во многом был накоплен в рамках деятельности ЮНСКОМ в Ираке [14]. 
нормального функционирования Организации ${ }^{10}$.

Дата вступления КЗХО в силу была определена лишь 31 октября 1996 г., когда Венгрия стала 65-м государством, ратифицировавшим Конвенцию. Согласно установленному требованию, КЗХО вступила в силу через 180 дней, 29 апреля 1997 г. За четыре года, прошедших до этого дня, Подготовительная комиссия провела 16 сессий, заложив основу для работы будущей ОЗХО. На момент вступления КЗХО в силу ее участниками стали 87 государств, в настоящее время - 192 государства. Россия присоединилась к Конвенции в 1997 г. $^{11}$ [16]. Особенности уничтожения химического оружия в России подробно рассмотрены в статье С.В. Петрова, стоявшего у истоков решения этой проблемы [17].

Краткое содержание КЗХО. Текст Конвенции - сложный документ объемом почти в двести страниц. Он включает Преамбулу, 24 статьи и три Приложения с лаконичными названиями - По химикатам, Осуществлению и проверке, а также Защите конфиденциальной информации.

В Преамбуле заявлено о намерении государств-участников запретить и ликвидировать все виды оружия массового уничтожения. В ней содержится ссылка на Женевский протокол 1925 г. и КБТО. Оба эти документа являются многосторонними документами, имеющими отношение к КЗХО. В Преамбуле также признается закрепленное в соответствующих соглашениях и принципах международного права запрещение использования гербицидов в качестве средства ведения войны и выражается желание государств-участников ускорять свое экономическое и техническое развитие в мирных целях.

В Статье I (Общие обязательства) запрещается разработка, производство, приобретение, сохранение, накопление, передача и применение химического оружия. В ней требуется, чтобы каждое из государств-участников уничтожило химическое оружие и объекты по производству химического оружия, находящиеся под его юрисдикцией или контролем, а также все химическое оружие, оставленное им на территории другого государства-участника. Всем государствам-участникам запрещается проводить военные приготовления к применению химического оружия, помогать или поощрять кого бы то ни было к проведению деятельности, запрещаемой Конвенцией, и использовать хи- мические средства борьбы с беспорядками в качестве средства ведения войны.

В Статье II (Определения и критерии) дается определение терминов, исключительно важных для КЗХО. В частности, дается определение самого понятия «химическое оружие»: «Химическое оружие» означает в совокупности или в отдельности следующее: a) токсичные химикаты и их прекурсоры, за исключением тех случаев, когда они предназначены для целей, не запрещаемых по настоящей Конвенции, при том условии, что их виды и количества соответствуют таким целям; b) боеприпасы и устройства, специально предназначенные для смертельного поражения или причинения иного вреда за счет токсических свойств, указанных в подпункте a) токсичных химикатов, высвобождаемых в результате применения таких боеприпасов и устройств; с) любое оборудование, специально предназначенное для использования непосредственно в связи с применением боеприпасов и устройств, указанных в подпункте b)».

Цели, не запрещаемые по Конвенции, включают в себя мирные цели, защиту от токсичных химикатов, военные цели, не связанные с применением токсичных химикатов как средства ведения войны, а также правоохранительные цели. Данное определение также включает в себя боеприпасы и устройства, специально предназначенные для высвобождения этих токсичных химикатов. И, наконец, оно относится к любому оборудованию, специально предназначенному для использования таких боеприпасов и устройств.

Данное в Конвенции определение «токсичный химикат» означает «любой химикат, который за счет своего химического воздействия на жизненные процессы может вызвать летальный исход, временный инкапаситирующий эффект или причинить постоянный вред человеку или животным. Сюда относятся все такие химикаты, независимо от их происхождения или способа их производства и независимо от того, произведены ли они на объектах, в боеприпасах или где-либо еще».

"Старое химическое оружие» означает химическое оружие, произведенное до 1925 г., или же произведенное в период между 1925 и 1946 гг., которое ухудшилось в такой степени, что оно уже не может использоваться в качестве химического оружия.

\footnotetext{
${ }_{10}$ Final Report of the Preparatory Commission for the Organisation for the Prohibition of Chemical Weapons. 9-15 апреля, 1997. URL: https://www.opcw.org/fileadmin/OPCW/PC_series/PCXVI/en/PCXVI37.pdf (дата обращения: 14.03.2020).

11 Федеральный закон № $138 Ф 3$ от 5 ноября 1997 г. «О ратификации Конвенции о запрещении разработки, производства, накопления и применения химического оружия и о его уничтожении» был принят Государственной думой РФ 31 октября 1997 г. и одобрен Советом Федерации 5 ноября того же года.
} 
«Оставленное химическое оружие» означает химическое оружие, включая старое, которое было оставлено государством-участником на территории другого государстваучастника без согласия последнего после 1 января 1925 г.

«Объект по производству химического оружия» означает, за исключением трех специально оговоренных случаев, любое оборудование, а также любое здание, вмещающее такое оборудование, которое было предназначено, построено или использовано в любое время с 1 января 1946 г. для производства или снаряжения химического оружия. «Химическое средство борьбы с беспорядками» означает любой не включенный в Приложение о химикатах Конвенции химикат, «способный быстро вызывать в организме человека раздражение органов чувств или физические расстройства, которые исчезают в течение короткого промежутка времени после прекращения воздействия».

Согласно Статье III (Объявления), каждое государство-участник, не позднее чем через 30 дней после того, как Конвенция вступит для него в силу, представляет ОЗХО подробные объявления в отношении химического оружия (в том числе старого и оставленного химического оружия) и объектов по его производству и хранению с общим планом их уничтожения. Кроме того, государства-участники должны указать объекты, предназначенные, построенные или использовавшиеся с 1 января 1946 г. преимущественно для разработки химического оружия, а также имеющиеся в наличии химические средства борьбы с беспорядками.

В Статье IV (Химическое оружие) и Статье V (Объекты по производству химического оружия), как и в Приложении по осуществлению и проверке (Приложение по проверке), содержатся подробные положения, касающиеся уничтожения химического оружия и объектов по его производству, а также проверки такого уничтожения. Оружие и объекты должны быть полностью уничтожены не позднее чем через 10 лет после вступления в силу Конвенции, т.е. к 29 апреля 2007 г. При чрезвычайных обстоятельствах окончательный срок уничтожения химического оружия может быть продлен еще до пяти лет при одобрении Конференцией государств-участников, т.е. до 29 апреля 2012 г. В 2011 г. государства-участники ОЗХО постановили, какие меры отчетности и транспарентности должны применяться, если окончательный продленный срок не будет соблюден, и что уничтожение оставшегося химического оружия должно быть завершено как можно скорее. В исключительных случаях объекты по производству химического оружия могут быть конверсированы в мирных целях, но только с одобрения Конференции государств-участников и по рекомендации Исполнительного совета. Кроме того, каждое государство-участник покрывает расходы по проверке со стороны О3ХО уничтожения его химического оружия и объектов по его производству.

В Статье VI (Деятельность, не запрещаемая по настоящей Конвенции), как и в Приложении по проверке, дается описание комплексного режима обычного наблюдения за химической промышленностью с помощью объявлений и инспекций на месте. Из-за возможного коммерческого применения многих химикатов и прекурсоров, КЗХО разбивает их на категории по трем спискам, содержащимся в Приложении по химикатам. Требования к объявлениям и инспекциям различаются по каждому списку, в зависимости от риска, который представляют собой содержащиеся в них химикаты для предмета и цели Конвенции.

В Статье VII (Национальные меры по осуществлению) говорится о мерах и законодательстве, которые государства-участники должны принять, чтобы обеспечить осуществление КЗХО на национальном уровне, и о создании или назначении Национального органа, который будет служить национальным координационным центром для О3ХО и других государств-участников.

В Статье VIII (Организация) предусматривается создание ОЗХО со штаб-квартирой в Гааге. Каждое государство-участник автоматически является членом ОЗХО и не может быть лишено своего членства в Организации. ОЗХО состоит из трех органов. Конференция государств-участников является главным органом Организации, она собирается на очередную сессию ежегодно, а ее специальные сессии созываются по необходимости. Исполнительный совет состоит из представителей 41 государства-участника из пяти региональных групп, он осуществляет надзор за деятельностью Секретариата и подотчетен Конференции. Технический секретариат выполняет практическую работу Организации. Самая большая часть ресурсов Секретариата направлена на осуществление деятельности по проверке. Генеральный директор назначается Конференцией и подотчетен ей и Исполнительному совету, в том числе в вопросах работы Секретариата.

В Статье IX (Консультации, сотрудничество и выяснение фактов) устанавливается возможность консультаций и выяснения фактов, если между государствами-участниками возникает озабоченность относительно возможного несоблюдения Конвенции. Как и в Приложении по проверке, в этой статье предусматривается проведение инспекций ОЗХО по 
запросу от государства-участника, с коротким сроком уведомления, на любом объекте или пункте на территории или в любом другом месте под юрисдикцией или контролем любого другого государства-участника с целью прояснения и урегулирования вопросов, касающихся возможного несоблюдения положений Конвенции. Государство-участник не может отказать в проведении инспекции по запросу, но имеет право предоставлять «регулируемый доступ», применяя меры для защиты чувствительных установок и информации, не связанной с химическим оружием.

$\mathrm{B}$ соответствии со Статьей $\mathrm{X}$ (Помощь и защита от химического оружия), государстваучастники сохраняют право разрабатывать и применять средства защиты от химического оружия. Государства-участники обязуются обеспечивать как можно более широкий обмен оборудованием, материалами и информацией о средствах защиты. Кроме того, каждое государство-участник должно обеспечить ОЗХО доступ к его ресурсам, которые могут быть использованы для оказания помощи государствам-участникам, против которых было совершено нападение с применением химического оружия, или против которых была направлена подобная угроза. С этой целью можно выбрать, по меньшей мере, одну из следующих трех мер: делать взносы в Добровольный фонд помощи, заключить соглашение с ОЗХО относительно получения помощи, или объявить, какого рода помощь могла бы быть предоставлена. Статья Х предусматривает обязательное наличие в ОЗХО банка данных с информацией из открытых источников по защите от химического оружия. Как и в Приложении по проверке, в Статье X предусмотрены процедуры расследования случаев предполагаемого применения химического оружия. Государства-участники могут инициировать расследование случаев предполагаемого применения химического оружия, запросив помощь согласно статье X.

В Статье XI (Экономическое и техническое развитие) поощряется максимально возможный широкий обмен химикатами, оборудованием и научно-технической информацией, связанной с развитием и применением химии в мирных целях. Государства-участники должны пересмотреть свои существующие национальные правила в области торговли химикатами, чтобы привести их в соответствие с предметом и целью Конвенции.

В Статье XII (Меры по исправлению положения и обеспечению соблюдения, включая санкции) устанавливается, что Конференция, принимая во внимание информацию, представленную Исполнительным советом, принимает необходимые меры по исправлению положения, если государство-участник не выполняет свои договорные обязательства. Конференция может, по рекомендации Исполнительного совета, применять санкции, ограничивать или приостанавливать права и привилегии государства-участника, предусмотренные Конвенцией. В особо серьезных случаях, Конференция доводит эти проблемы до сведения Генеральной Ассамблеи Организации Объединенных Наций и Совета Безопасности ООН.

В Статье XIII (Связь с другими международными соглашениями) устанавливается, что ничто в КЗХО не ограничивает и не умаляет обязательства государств по Женевскому протоколу 1925 г. и КБТО.

Статья XIV (Урегулирование споров) позволяет урегулировать споры, касающиеся применения или толкования КЗХО. При возникновении спора между государствами-участниками или любым государством-участником и $\mathrm{O} 3 \mathrm{XO}$, соответствующие участники обязуются проводить совместные консультации для его скорейшего урегулирования мирными средствами. Стороны могут обратиться за помощью в Исполнительный совет, к Конференции государств-участников или в Международный суд.

Согласно Статье XV (Поправки), в статьи и приложения Конвенции могут вноситься поправки на Конференции по рассмотрению поправок. Такая Конференция созывается в том случае, если не менее одной трети всех государств-участников уведомят Генерального директора, в течение 30 дней после распространения предложения о поправке, о том, что они желают дальнейшего рассмотрения такого предложения. В этой статье содержится положение об упрощенной процедуре внесения поправок, если эти изменения приложений Конвенции касаются лишь вопросов административного или технического характера.

В Статье XVI (Срок действия и выход из Конвенции) устанавливается, что КЗХО является бессрочной. Каждое государство-участник имеет право выйти из КЗХО, но только в том случае, если оно решит, что его высшие интересы поставлены под угрозу из-за чрезвычайных событий, касающихся предмета Конвенции. Государство должно уведомить о своем выходе за 90 дней все другие государства-участники, Исполнительный совет, Генерального Секретаря ООН и Совет Безопасности, изложив, каким образом эти события поставили под угрозу его высшие интересы.

В Статье XVII (Статус приложений) определяется, что Приложения составляют неотьемлемую часть КЗХО.

В Статье XVIII (Подписание) определяется, что КЗХО открыта к подписанию до ее вступления в силу. 
В Статье XIX (Ратификация) указывается, что государства, подписавшие Конвенцию, должны ее ратифицировать согласно их соответствующим конституционным процедурам.

В Статье XX (Присоединение), государствам, не подписавшим КЗХО до ее вступления в силу, разрешается присоединиться к ней в любое время впоследствии.

В Статье XXI (Вступление в силу) заявлено, что КЗХО вступает в силу через 180 дней после даты сдачи на хранение 65-й ратификационной грамоты. Для государств, чьи ратификационные грамоты или документы о присоединении сданы на хранение после вступления в силу, Конвенция вступает в силу через 30 дней после сдачи на хранение этих документов.

В Статье XXII (Оговорки) говорится, что статьи Конвенции не подлежат оговоркам, и что ее приложения не подлежат оговоркам, несовместимым с ее предметом и целью.

Согласно Статье XXIII (Депозитарий), Генеральный секретарь ООН назначается лицом, получающим все ратификационные грамоты и документы о присоединении.

В Статье XXIV (Аутентичные тексты) устанавливается, что тексты КЗХО на английском, арабском, испанском, китайском, русском и французском языках являются равно аутентичными.

Приложение по химикатам содержит три Списка, или Перечня, токсичных химикатов и их прекурсоров. В отношении перечисленных в каждом из Списков химикатов осуществляется деятельность по проверке разного уровня. Приводятся основные принципы, позволяющие определить, следует ли включить тот или иной химикат в один из Списков.

Приложение по осуществлению и проверке («Приложение по проверке») составляет преобладающую часть Конвенции. Оно содержит одиннадцать подробных частей, касающихся уничтожения химического оружия и ОПХО и описание процедур проверки химического оружия, ОПХО и объектов химической промышленности. Оно также включает в себя подробное описание процедур проведения инспекций по запросу и расследований предпола- гаемого применения и ограничений торговли списочными химикатами с государствами, не являющимися участниками КЗХО.

В Приложении по защите конфиденциальной информации («Приложение по конфиденциальности») определяются принципы обращения с конфиденциальной информацией, набора и поведения персонала ОЗХО. В нем также дается описание процедур и мер по обеспечению конфиденциальности чувствительной информации и установок в ходе проверок и дается описание процедур, применимых в случае нарушения конфиденциальности.

Уничтожение российского химического оружия было начато в тяжелейших условиях распада СССР, смены политической формации и последовавшего за этим обрушения экономики. Исторической вехой на пути выполнения Россией международных обязательств в области химического разоружения стало Постановление Правительства Российской Федерации от 21 марта 1996 г. № 305, утвердившее Федеральную целевую программу «Уничтожение запасов химического оружия в Российской Федерации». В 2000 г. для ускорения ее реализации было создано Федеральное бюджетное учреждение «Федеральное управление по безопасному хранению и уничтожению химического оружия при Министерстве промышленности и торговли Российской Федерации» (Федеральное управление). Благодаря научным и технологическим наработкам, сделанным еще в советское время, а также чрезвычайным усилиям и таланту специалистов войск РХБ защиты Вооруженных Сил Российской Федерации, Федерального управления и ряда гражданских научно-исследовательских организаций, программу удалось завершить на три года раньше намеченного срока. Последний российский химический снаряд уничтожен 27 сентября 2017 г. на специальном предприятии в удмуртском поселке Кизнер Российская Федерация выполнила все взятые на себя в рамках КЗХО обязательства.

\section{Информация о конфликте интересов}

Автор заявляет, что исследования проводились при отсутствии любых коммерческих или финансовых отношений, которые могли бы быть истолкованы как потенциальный конфликт интересов.

\section{Сведения о рецензировании}

Статья прошла открытое рецензирование двумя рецензентами, специалистами в данной области. Рецензии находятся в редакции журнала и в РИНЦе. 


\section{Список источников}

1. Антонов Н.С. Химическое оружие на рубеже двух столетий. М. 1994.

2. Шило Н.И. Первые попытки запрещения химического оружия // Вестник войск РХБ защиты. 2018. T. 2. № 1. C. 48-69. https://doi.org/10.35825/25875728-2018-2-1-48-69

3. Мартенс Ф. Восточная война и Брюссельская конференция 1874-1878 г. СПб. 1879.

4. Супотницкий М.В., Петров С.В., Ковтун В.А. Химическое оружие в Первой мировой войне. M. 2020.

5. Александров В.Н., Емельянов В.И. Отравляющие вещества. М. 1990.

6. Урланис Б.Ц. История военных потерь. СПб. 1998.

7. Simon J., Hook R. Word war I gas warfare tactics and equipment. Oxford: Osprey Publishing, 2007.

8. Medical aspects of chemical and biological warfare / Ed. Sidell F.R., Tafuqi E.T., Franz D.R. Washington. 1997.

9. Протокол о запрещении применения на войне удушливых, ядовитых или других подобных газов и бактериологических средств, 17 июня 1925 года // Сборник документов и материалов, регламентирующих обеспечение выполнения Российской Федерации международных обязательств по запрещению биологического и токсинного оружия. М. 2004.

10. Конвенция о запрещении разработки, производства и накопления запасов бактериологического (биологического) и токсинного оружия и об их уничтожении // Сборник документов и материалов, регламентирующих обеспечение выполнения Российской Федерации международных обязательств по запрещению биологического и токсинного оружия. М. 2004.

11. Пунжин С.М. Химическое оружие и международное право. М. 2009.

12. The Chemical Weapons Bill (Bill 2 1995/96) // House of Commons Library Research Paper 95/116. P. 9. URL: https://commonslibrary.parliament.uk/researchbriefings/rp95-116/

13. Dando M. Biological warfare in the 21st century. N.Y. 1994.

14. Супотницкий М.В., Шило Н.И., Ковтун В.А. Применение химического оружия в ирано-иракской войне 1980-1988 годов. 4. Ликвидация химического оружия Ирака // Вестник войск РХБ защиты. 2020. T. 4. № 2. C. 131-159. https://doi.org/10.35825/25875728-2020-4-2-131-159

15. Конвенция о запрещении разработки, производства, накопления и применения химического оружия и о его уничтожении. ООН. 1993.

16. Смирнов И.В., Завриев С.К. Химическое оружие: современное состояние и контроль за выполнением международных соглашений // Мировая экономика и международные отношения. 2018. Т. 62. № 1. С. 76-84.

17. Петров С.В. Как создавался фундамент государственной программы уничтожения химического оружия в России // Вестник войск РХБ защиты. 2018. T. 2. № 1. C. 24-36. https://doi.org/10.35825/2587-57282018-2-1-24-36

\section{Об авторе}

Федеральное государственное бюджетное учреждение «27 Научный центр» Министерства обороны Российской Федерации, 105005, г. Москва, Бригадирский переулок, д. 13.

Фатеенков Владимир Николаевич. Начальник отдела, кандидат военных наук, доцент, профессор АВН.

Контактная информация для всех авторов: 27nc_1@mil.ru Контактное лицо: Корнеев Дмитрий Олегович, 27nc_1@mil.ru 


\title{
The Convention on the Prohibition of the Development, Production, Stockpiling and Use of Chemical Weapons and on their Destruction: History of Signing and Key Points
}

\author{
V.N. Fateenkov \\ Federal State Budgetary Establishment «27 Scientific Centre» of the Ministry \\ of Defence of the Russian Federation, Brigadirskii Lane 13, \\ Moscow 105005, Russian Federation
}

\begin{abstract}
The Convention on the Prohibition of the Development, Production, Stockpiling and Use of Chemical Weapons and on their Destruction (the Chemical Weapons Convention or CWC) was approved by the U.N. General Assembly on 30 November 1992. The treaty entered into force on 29 April 1997. The aim of this work was to study the history of signing of the CWC and its key points. First attempts to develop an international agreement restricting the use of poisons and various toxic substances in hostilities have been made in the 17th century, when the 1675 Strasbourg Agreement between France and the Holy Roman Empire banned the use of poisoned bullets. During the First and Second Peace Conferences in The Hague (1899 and 1907), its participants pledged to refrain from employing "poison or poisoned arms» and from employing «arms, projectiles, or material of a nature to cause superfluous injury». The First World War showed that this ban turned out to be ineffective, and chemical weapons appeared on the battlefield. After the war, the «Protocol for the Prohibition of the Use in War of Asphyxiating, Poisonous or Other Gases, and of Bacteriological Methods of Warfare», known as the Geneva Protocol of 1925, was developed. But this document did not ban the elaboration and the production of chemical weapons. The High Contracting Parties agreed not to use «asphyxiating, poisonous or other gases, and of all analogous liquids, materials or devices» against those States only, that acceded to the Protocol. Moreover, many States-Parties reserved their right to use chemical weapons in response to a first use by an enemy. The Iran-Iraq War (1980-1988) showed the ineffectiveness of the Geneva Protocol of 1925. Iraq's massive use of chemical weapons against Iranian troops has accelerated the process of developing an international document - the CWC, the world's first multilateral disarmament agreement, which provided for the verifiable elimination, within the prescribed time limit, of an entire class of weapons of mass destruction chemical weapons. Nowadays 192 states have become parties to the CWC. The Russian Federation fully complied with the obligations undertaken by the CWC, the last Russian chemical munition was destroyed in September 2017.
\end{abstract}

Keywords: Geneva Protocol 1925; The Chemical Weapons Convention (CWC); The Biological and Toxin Weapons Convention (BTWC); The United Nations (UN); The Organisation for the Prohibition of Chemical Weapons (OPCW); poisonous agents; toxic chemicals; destruction; chemical weapons.

For citation: Fateenkov V.N. The Convention on the Prohibition of the Development, Production, Stockpiling and Use of Chemical Weapons and on their Destruction: History of Signing and Key Points // Journal of NBC Protection Corps. 2020. V. 4. № 2. P. 104-115. https://doi.org/10.35825/2587-5728-2020-4-2-104-115

Conflict of interest statement

The author declares that the research was conducted in the absence of any commercial or financial relationship that could be construed as a potential conflict of interest.

Peer review information

The article has been peer reviewed by two experts in the respective field. Peer reviews are available from the Editorial Board and from Russian Science Citation Index database. 


\section{References}

1. Antonov N.S. Chemical Weapons at the Turn of the Century. Moscow, 1994 (in Russian).

2. Shilo N.I. First Attempts to Ban Chemical Weapons // Journal of NBC Protection Corps. 2018. V. 2. № 1. P. 48-69 https://doi.org/10.35825/2587-57282018-2-1-48-69 (in Russian).

3. Martens F. The Eastern War and the Brussels Conference 1874-1878. St. Petersburg.1879. 596 p., with att. (46 p.) (in Russian).

4. Supotnitskiy M.V., Petrov S.V., Kovtun V.A. Chemical Weapons in World War One. Moscow, 2020 (in Russian).

5. Alexandrov V.N., Emelyanov V.I. Poisonous Substances. M., 1990 (in Russian).

6. Urlanis B.Ts. History of Military Losses. St. Petersburg, 1998 (in Russian).

7. Simon J., Hook R. Word War I Gas Warfare Tactics and Equipment. Oxford: Osprey Publishing, 2007.

8. Medical Aspects of Chemical and Biological Warfare / Ed. Sidell F.R., Tafuqi E.T., Franz D.R. Washington. 1997.

9. Protocol for the Prohibition of the Use in War of Asphyxiating, Poisonous or Other Gases, and of Bacteriological Methods of Warfare. June 17, 1925 // Documents and Materials on the Implementation of the Russian Federation's International Obligations to Ban Biological and Toxin Weapons. Moscow, 2004 (in Russian).

10. The Convention on the Prohibition of the Development, Production and Stockpiling of
Bacteriological (Biological) and Toxin Weapons and on their Destruction // Documents and Materials on the Implementation of the Russian Federation's International Obligations to Ban Biological and Toxin Weapons. Moscow, 2004 (in Russian).

11. Punzhin S.M. Chemical Weapons and International Law. Moscow, 2009 (in Russian).

12. The Chemical Weapons Bill (Bill 2 1995/96) // House of Commons Library Research Paper 95/116. P. 9. URL: https://commonslibrary.parliament.uk/researchbriefings/rp95-116/

13. Dando M. Biological Warfare in the 21st Century. N.Y. 1994.

14. Supotnitskiy M.V., Shilo N.I., Kovtun V.A. Chemical Weapons in the Iran-Iraq War (1980-1988). 4. The Destruction of Iraqi Chemical Weapons // Journal of NBC Protection Corps. 2020. V. 4. № 2. P. 131-159 https:// doi.org/10.35825/2587-5728-2020-4-2-131-159 (in Russian).

15. The Convention on the Prohibition of the Development, Production, Stockpiling and Use of Chemical Weapons and on their Destruction. UN. 1993.

16. Smirnov I.V., Zavriev S.K. Chemical Weapons: State-Of-The-Art, Control of the Implementation of International Agreements // World Economy and International Relations. 2018. V. 62. № 1. P. 76-84 (in Russian).

17. Petrov S.V. The Start of the State Program of CW Destruction in Russia // Journal of NBC Protection Corps. 2018. V. 2. № 1. P. 24-36. https://doi.org/10.35825/25875728-2018-2-1-24-36 (in Russian).

Author

Federal State Budgetary Establishment «27 Scientific Centre» of the Ministry of Defence of the Russian Federation. Brigadirskii Lane 13, Moscow 105005, Russian Federation.

Vladimir Nikolaevich Fateenkov. Chief of the Department. Candidate of Military Sciences, Associate Professor, Professor of the Academy of Military Sciences.

Contact information for all authors: 27nc_1@mil.ru Contact person: Korneev Dmitry Olegovich; 27nc_1@mil.ru 